\title{
PERBANDINGAN RISIKO DAN PENGEMBALIAN ANTARA SAHAM-SAHAM BERBASIS SYARIAH DAN NON SYARIAH YANG TERCATAT DI BURSA EFEK INDONESIA
}

\author{
Adhytya Bagus Rizkianto \\ Department of Management FEB UMM \\ E-mail: adhytbagus@gmail.com
}

\begin{abstract}
This research aims to determine the significant differentiation on risk and returns between sharia and non-sharia stocks based on Indonesian Stock Exchange.

The Independent Sample T-Test was employed as an analytical tool. To measure the significant level of differentiation is using critical value $<0,05$. The result shows that there was no significant differentiation of the risk and returns between sharia and non-sharia stocks based. The analysis also shows that the risk and returns of non-sharia higher than sharia stock based. Based on the results of data analysis, it could be recommended that investors be better to invest in sharia stock based because it has a lower risk than non-sharia stock based.
\end{abstract}

\section{Keywords : Risk, Return, Sharia and Non-Sharia Stock Based}

\section{PENDAHULUAN}

Pertumbuhan Pasar Modal Indonesia selama lima tahun terakhir (tahun 2010-2014) menunjukkan peningkatan dan sedikit penurunan. Pada tahun 2010 perdagangan saham di Bursa Efek ditutup pada level 3.703,51 menjadi 3.821,99 pada tahun 2011. Pada tahun 2012 juga mengalami peningkatan, yaitu sebesar 4.316,69. Pada tahun 2013 mengalami sedikit penurunan yaitu pada level 4.274,18 atau menurun sekitar 1,61\%. Pada tahun 2014 Bursa Efek Indonesia mencatatkan raihan positif dengan menutup perdagangan pada level 5.226,95 dan dengan raihan tersebut pertumbuhan perdagangan saham adalah sebesar
41,14\% selama lima tahun terakhir (www.idx.co.id).

Berdasarkan hasil positif yang dicapai oleh Bursa Efek Indonesia (BEI) selama lima tahun terakhir, berinvestasi di pasar modal merupakan salah satu jenis investasi yang menjanjikan bagi para investor yang ingin mendapatkan pengembalian atas investasinya dengan optimal. Tujuan utama investor dalam menginvestasikan dananya yaitu untuk mendapatkan tingkat pengembalian atau keuntungan yang tinggi dari instrument investasi yang dipilihnya. Hal lain yang perlu diperhatikan seorang investor selain tingkat pengembalian yang tinggi yaitu risiko yang terkandung di dalamnya. 
Indonesia merupakan negara yang luas dengan jumlah sebesar 237.641.326 penduduk berdasarkan

hasil sensus Badan Pusat Statistik (BPS) tahun 2010. Sekitar $87 \%$ dari total penduduk Indonesia merupakan penduduk beragama Islam, yaitu 207.176.162 penduduk (www.bps.go.id). Penduduk Indonesia yang mayoritas muslim ini mencerminkan kebutuhan masyarakat akan sebuah investasi berbasis syariah. Terkait investasi yang dibutuhkan oleh masyarakat muslim di Indonesia, Bursa Efek Indonesia (BEI) menerbitkan indeks saham berbasis syariah yaitu Jakarta Islamic Index (JII) pada tahun 2000.

Fakta di lapangan menunjukkan bahwa besarnya jumlah penduduk muslim di Indonesia tidak sebanding dengan jumlah investor saham syariah. Jumlah investor saham berbasis syariah di Indonesia masih sangat sedikit yaitu sekitar $0,2 \%$ dari total penduduk Indonesia (www.republika.co.id). Berdasar catatan Bursa Efek Indonesia yang dimuat dalam surat kabar online (economy.okezone.com) jumlah investor saham syariah masih berjumlah 3.400 dari total 400.000 investor atau sekitar $0,85 \%$. Jumlah investor saham syariah tersebut menunjukkan keraguan para investor terhadap kinerja saham syariah masih tinggi.

Nilai indeks saham merupakan salah satu pertimbangan para investor untuk berinvestasi pada saham syariah atau non syariah. Nilai indeks saham dapat memberikan gambaran bagi para investor tentang kinerja saham-saham dalam suatu indeks. Salah satu indeks syariah dan non syariah yang menjadi pertimbangan investor adalah Jakarta Islamic Index (JII) dan Kompas100. Jakarta Islamic Index (JII) merupakan indeks syariah yang terdiri dari 30 . Indeks Kompas100 merupakan indeks non syariah yang terdiri dari 100 saham. Perbandingan antara nilai indeks dari JII dan Kompas100 dapat dilihat pada Tabel 1.

Tabel 1. Perbandingan Nilai Indeks Saham Syariah dan Non Syariah

\begin{tabular}{|c|c|c|}
\hline \multirow{2}{*}{ Tahun } & Indeks Non Syariah & Indeks Syariah \\
\cline { 2 - 3 } & Kompas 100 & Jakarta Islamic Index (JII) \\
\hline 2010 & 860,70 & 532,90 \\
\hline 2011 & 865,20 & 537,03 \\
\hline 2012 & 946,27 & 594,79 \\
\hline 2013 & 910,09 & 585,11 \\
\hline 2014 & $1.144,63$ & 691,04 \\
\hline
\end{tabular}

Sumber: www.idx.co.id diunduh pada 05 Januari 2016

Berdasarkan data dari BEI pada tabel di atas selama tahun 20102014, nilai indeks saham non syariah yang diwakilkan Kompas100 memang lebih baik jika dibandingkan nilai indeks saham syariah yang diwakilkan JII. Pada tahun 2010 dan 2011 nilai Indeks JII sebesar 532,90 dan 537,03. Pada tahun yang sama nilai Indeks Kompas 100 lebih besar, 
yaitu sebesar 860,70 dan 865, 20. Pada tahun 2012, 2013, dan 2014 nilai Indeks Kompas100 juga masih lebih baik, yaitu sebesar 946,27; 910,09; dan 1.144,63. Sedangkan nilai Indeks JII adalah sebesar 594,79; 585,11; dan 691,04.

Dalam pengambilan keputusan investasi pada saham dengan melihat nilai indeks saham saja tidak cukup pasti diketahui seberapa besar risiko dan pengembalian yang diperoleh. Untuk mengetahui seberapa besar pengembalian dan risiko dari saham berbasis syariah dan non syariah, perlu diadakan perbandingan terhadap kedua jenis saham tersebut dengan menggunakan obyek saham yang murni syariah pada JII dan murni non syariah pada Indeks Kompas 100. Selain itu penelitian ini juga diharapkan dapat menjawab keraguan investor terhadap saham syariah yang saat ini jumlah investor saham syariah masih $0,85 \%$ dari total keseluruhan investor di pasar modal.

Beberapa peneliti telah melakukan penelitian yang sejenis, yaitu pada saham-saham yang terdaftar dalam JII dan Indeks LQ45 dengan hasil sahamsaham pada JII memiliki kinerja yang lebih baik dari saham-saham pada Indeks LQ45 tetapi perbedaan tersebut tidak signifikan. Pada penelitian ini digunakan obyek yang berbeda, yaitu saham-saham pada JII dan Kompas100. Berdasarkan nilai indeks, Kompas100 lebih unggul daripada JII. Pada penelitian terdahulu saham-saham syariah yang diambil dari Indeks JII lebih baik dari saham-saham non syariah dari Indeks LQ45.

Berdasarkan uraian tersebut, maka peneliti tertarik untuk melakukan penelitian dengan judul
"Perbandingan Risiko dan Pengembalian antara Saham-saham Berbasis Syariah dan Non Syariah yang Tercatat di Bursa Efek Indonesia."

Berdasarkan latar belakang masalah tentang perbandingan risiko (risk) dan pengembalian (return) antara saham-saham berbasis syariah dan non syariah yang tercatat di Bursa Efek Indonesia dapat ditemukan sebuah masalah penelitian, yaitu apakah ada perbedaan yang signifikan atas risiko (risk) dan pengembalian (return) antara saham-saham berbasis syariah dan non syariah.

Tujuan dilakukannya penelitian terhadap risiko (risk) dan pengembalian (return) antara saham-saham yang berbasis syariah dan non syariah ini adalah untuk mengetahui apakah ada perbedaan yang signifikan atas risiko (risk) dan pengembalian (return) antara saham-saham berbasis syariah dan non syariah.

\section{TINJAUAN PUSTAKA}

Bodie, dkk dalam Zubir (2011: 2) mengatakan bahwa ada dua langkah yang harus dilakukan dalam proses investasi saham, yaitu: Pertama, melakukan analisis terhadap return dan risiko saham-saham yang akan dimasukkan ke dalam portofolio. Kedua adalah membentuk portofolio optimal dari saham-saham yang dipilih. Aktivitas ini meliputi mengalokasikan dana, dan menghitung return dan risiko berbagai portofolio, dan memilih portofolio yang terbaik.

Menurut Jogiyanto (2013: 257) risiko sering dihubungkan dengan penyimpangan atau deviasi dari outcome yang diterima dengan yang diekspektasi. Untuk menghitung risiko, metode yang banyak 
digunakan adalah deviasi standar (standard deviation) yang mengukur penyimpangan nilai-nilai yang sudah terjadi dengan nilai ekspektasinya.

Pengembalian atau return meruakan hasil yang diperoleh dari investasi. Return dapat berupa return realisasi yang merupakan return sudah terjadi atau return ekspektasi yang merupakan return yang belum terjadi tetapi yang diharapkan akan terjadi di masa mendatang. Return realisasi penting karena digunakan sebagai salah satu pengukur kinerja dari perusahaan. Return realisasi ini juga berguna sebagai dasar penentuan return ekspektasi dan risiko di masa meendatang (Jogiyanto 2013: 205).

Menurut Jogiyanto (2013: 206) salah satu pengukuran return yang dapat digunakan untuk mengukur return realisasi adalah return total. Menurut Jogiyanto (2013: 225) untuk menghitung return ekspektasi berdasar data-data historis dapat menggunakan metode rata-rata (mean method).

Secara fundamental harga suatu jenis saham dipengaruhi oleh kinerja perusahaan dan kemungkinan risiko yang dihadapi perusahaan. Kinerja perusahaan tercermin dari laba operasional dan laba bersih per saham serta beberapa rasio keuangan yang menggambarkan kekuatan manajemen dalam mengelola perusahaan. Risiko absolut

menghadapi siklus ekonomi serta faktor makro ekonomi dan makro nonekonomi. Dengan kata lain, kinerja perusahaan dan risiko yang dihadapi dipengaruhi oleh faktor makro dan mikro ekonomi (Samsul 2006: 200).

Peraturan yang disyaratkan pada saham berbasis syariah dan saham berbasis non syariah memang memiliki beberapa perbedaan. Berdasarkan keputusan Ketua Bapepam dan LK nomor Kep208/BL/2012 saham syariah tidak boleh memiliki total utang yang berbasis bunga dibandingkan total aset tidak lebih dari $45 \%$ dan pendapatan bunga serta tidak halal lainnya dibandingkan dengan total pendapatan tidak boleh melebihi $10 \%$. Perusahaan pada efek syariah juga tidak diperbolehkan menjual produkproduk yang tidak sesuai dengan syariah Islam, seperti minuman keras, jasa asuransi konvensional, dan jasa perbankan.

Kerangka pikir ini dibuat untuk menjelaskan bagaimana seorang investor akan mengambil keputusan investasi saham berbasis syariah dan saham berbasis non syariah. Adapun kerangka pemikiran dapat dilihat pada Gambar

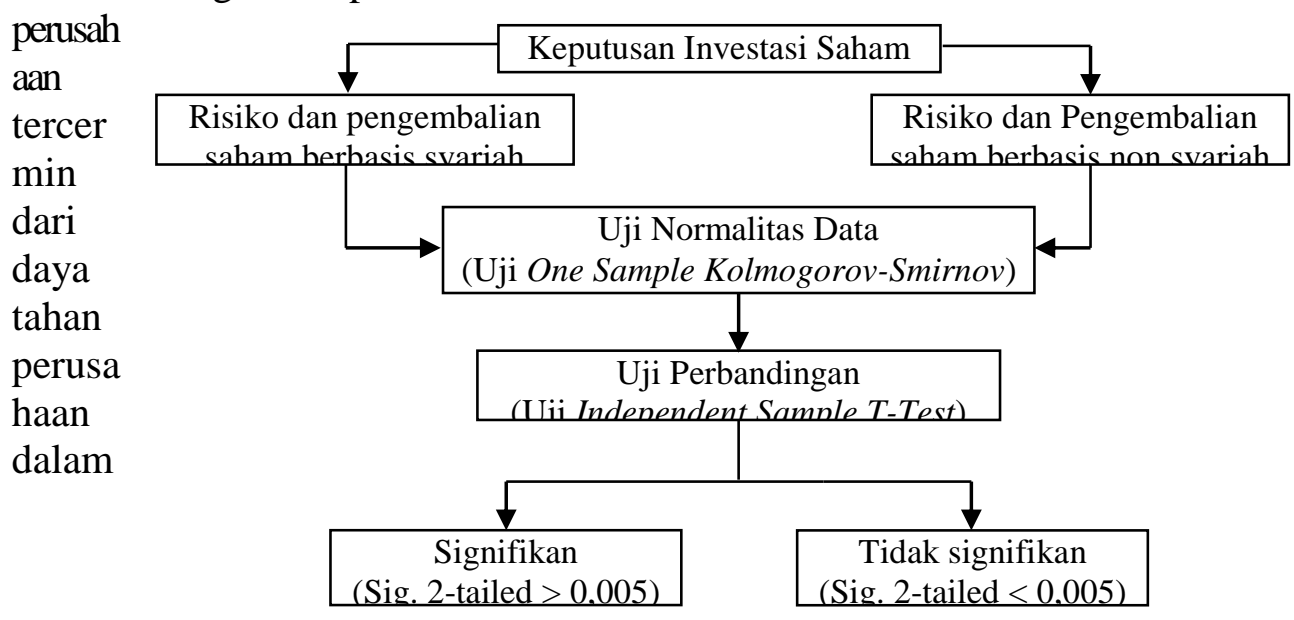


latar belakang masalah dan rumusuan masalah, hipotesis dalam penelitian ini dapat dirumuskan bahwa ada perbedaan yang signifikan atas risiko (risk) dan pengembalian (return) antara saham-saham berbasis syariah dan non syariah.

\section{METODE PENELITIAN}

Jenis peneliti ini merupakan jenis penelitian survei, dalam arti hasil kesimpulan penelitian ini digunakan untuk mengeneralisasi risiko dan pengembalian investasi pada saham berbasis syariah dan saham berbasis non syariah. Survei dilakukan terhadap saham-saham berbasis syariah dan non syariah yang terdaftar di Bursa Efek Indonesia selama tahun 2010-2014.

Variabel pertama yang digunakan dalam penelitian ini adalah risiko yang dihitung dalam periode bulanan selama tahun 20102014 menggunakan harga penutupan saham setiap bulan, yang diukur dengan menggunakan standar deviasi. Risiko (risk) dapat dihitung menggunakan rumus sebagai berikut (Jogiyanto 2013: 229):

$$
S D=\sqrt{\frac{\sum_{i=1}^{n}\left[X_{i}-E\left(X_{i}\right)\right]^{2}}{n-1}}
$$

Keterangan:

$\mathrm{SD}$ : standard deviation, $\mathrm{X}_{\mathrm{i}}$ : nilai ke-i,

$\mathrm{E}\left(\mathrm{X}_{\mathrm{i}}\right)$ : nilai ekspektasian,

n : jumlah dari observasi data historis untuk sampel besar dengan $\mathrm{n}$ (paling sedikit 30 observassi) dan untuk sampel kecil (n-1).

Variabel kedua dalam penelitian ini adalah pengembalian yang terdiri dari return realisasi dan return ekspektasi. Return realisasi yang dihitung dalam penelitian ini adalah return bulanan selama tahun 2010-2014 menggunakan data historis berupa harga penutupan saham setiap bulan. Return realisasi dapat dihitung menggunakan rumus sebagai berikut (Jogiyanto 2013: 207):

Return Saham $=\frac{P_{t}-P_{t-1}+D_{t}}{P_{t-1}}$

Keterangan:

$\mathrm{P}_{\mathrm{t}}$ : harga, yaitu harga untuk waktu t.

$\mathrm{P}_{\mathrm{t}-1}$ : harga, yaitu harga untuk waktu sebelumnya (kemarin, bulan lalu, tahun lalu, dan seterusnya).

$D_{t}$ : dividen periodik

Untuk menghitung return ekspektasi berdasar data-data historis dapat menggunakan rumus sebagai berikut (Jogiyanto 2013: 225):

$$
E\left(R_{i}\right)=\frac{\sum R_{i}}{n}
$$

Keterangan:

$\mathrm{E}\left(\mathrm{R}_{\mathrm{i}}\right)$ : return ekspektasi

$\sum \mathrm{R}_{\mathrm{i}}$ : total return selama periode pengamatan

n : jumlah periode pengamatan

Data yang digunakan pada penelitian ini adalah data sekunder yang diunduh melalui www.yahoofinance.com. Populasi dalam penelitian ini adalah sahamsaham yang termasuk dalam indeks JII dan indeks Kompas100 periode 2010-2014. Metode pengambilan sampel menggunakan metode purposive sampling. Teknik pengumpulan data yang digunakan pada penelitian ini adalah teknik pengamatan dan dokumentasi.

Teknik analisis data yang digunakan dalam penelitian ini melalui beberapa tahap. Tahap pertama yang dilakukan setelah data terkumpul dan diperiksa kebenarannya 
adalah uji normalitas data menggunakan Uji One-Sample Kolmogorov-Smirnov. Berdasarkan hasil uji normalitas data apabila data berditribusi normal maka menggunakan Uji Independent Sample T-Test untuk uji hipotesis, jika data tidak berdistribusi normal maka menggunakan Uji Mann Whitney.

\section{HASIL PENELITAN DAN PEMBAHASAN}

Berdasarkan kriteria pengambilan sampel maka diperoleh 22 sampel yang terdiri dari 12 emiten saham berbasis syariah dan 10 emiten saham berbasis non syariah yang terdaftar di Bursa Efek Indonesia selama tahun 2010-2014.

Berdasarkan hasil Uji OneSample Kolmogorov-Smirnov dapat diketahui bahwa nilai Asymp. Sig. (2tailed) untuk data risiko saham syariah memiliki tingkat signifikansi $0,0,058$, artinya nilai ini lebih besar dari tingkat signifikansi yang telah ditentukan yaitu sebesar 0,05 sehingga data berdistribusi normal. Untuk data risiko saham non syariah juga memiliki tingkat signifikansi di atas 0,05 , yaitu 0,100 sehingga data berdistribusi normal. Untuk data pengembalian saham syariah dan pengembalian saham non syariah masing-masing juga memiliki tingkat signifikansi di atas 0,05, yaitu 0,907 dan 0,929 sehingga data berdistribusi normal.

Uji hipotesis yang digunakan dalam penelitian adalah Uji Independent Sample T-Test yang didasari dengan hasil dari uji normalitas data menggunakan Uji One Sample Kolmogorov-Smirnov dengan asumsi jika data berdistribusi nomal maka menggunakan Uji Independent Sample T-Test.

Berdasarkan hasil uji hipotesis pertama dapat diketahui bahwa data risiko antara saham berbasis syariah dan non syariah memiliki varians yang tidak sama. Hal ini terbukti dari tingkat signifikansi pada tabel Levene's Test for Equality of Variances lebih kecil dari 0,05, yaitu 0,029. Berdasarkan hasil tersebut untuk melihat kesimpulan dari hasil uji statistik Independent Sample T-Test menggunakan Equal Variances Not Assumed.

Saham berbasis syariah memiliki risiko sebesar 0,00807 dan saham berbasis non syariah memiliki risiko sebesar 0,00938. Pada kolom Mean Difference nilainya adalah 0,001313 yang mencerminkan seberapa besar perbedaan risiko di antara kedua jenis saham. Menggunakan tingkat signifikansi sebesr 0,05, dengan asumsi Equal Variances Not Assumed menunjukkan hasil bahwa nilai probabilitas (Sig 2-tailed) sebesar 0,274 yang nilainya di atas level signifikan 0,05 yang artinya adalah $\mathrm{H}_{0}$ diterima atau tidak ada perbedaan yang signifikan atas risiko antara saham berbasis syariah dan non syariah.

Berdasarkan hasil uji hipotesis kedua dapat diketahui bahwa data pengembalian antara saham berbasis syariah dan berbasis non syariah memiliki varians yang sama. Hal ini terbukti dari tingkat signifikansi pada tabel Levene's Test for Equality of Variances lebih besar dari 0,05 , yaitu 0,527. Sehingga untuk melihat kesimpulan dari hasil Uji Independent Sample T-Test 
menggunakan Equal Variances Assumed.

Berdasarkan asumsi Equal Variances Assumed menunjukkan bahwa nilai probabilitas (Sig. 2tailed) sebesar 0,552 yang nilainya di atas level signifikan 0,05. Berdasarkan hasil tersebut maka $\mathrm{H}_{0}$ diterima atau tidak ada perbedaan yang signifikan atas pengembalian antara saham berbasis syariah dan non syariah. Output uji hipotesis juga menunjukkan bahwa antara pengembalian saham berbasis syariah dan berbasis non syariah terdapat perbedaan sebesar 0,002740 dimana tingkat pengembalian saham berbasis non syariah adalah 0,01914, sedangkan saham berbasis syariah adalah 0,01640.

Berdasarkan hasil uji perbandingan dapat dilihat bahwa saham berbasis non syariah memiliki risiko yang lebih tinggi daripada saham berbasis syariah. Hal ini berarti sesuai dengan konsep high risk high return, dimana saham berbasis non syariah juga memiliki pengembalian yang lebih tinggi daripada saham berbasis syariah. Hasil uji perbandingan risiko dan pengembalian menunjukkan hasil yang sama dimana risiko dan pengembalian antara saham berbasis syariah dan non syariah tidak ada perbedaan yang signifikan.

Berdasarkan

hasil perhitungan risiko antara saham berbasis syariah dan non syariah pada penelitian ini menunjukkan bahwa saham berbasis non syariah memiliki risiko yang lebih tinggi dibandingkan dengan risiko saham berbasis syariah. Perbedaan risiko antara saham berbasis syariah dan non syariah adalah 0,001313 . Hasil uji perbandingan risiko menunjukkan bahwa tidak ada perbedaan yang signifikan atas risiko antara sahamsaham berbasis syariah dan non syariah.

Penelitian ini konsisten
dengan penelitian Wijiyantoro (2014) yang diperoleh hasil bahwa tidak terdapat perbedaan yang signifikan antara risiko saham berbasis syariah dan non syariah. Hasil perhitungan risiko pada penelitian Wijiyantoro (2014) menunjukkan bahwa risiko saham syariah lebih besar daripada saham non syariah. Hubungan antara return dan risiko dalam penelitiannya juga menunjukkan hubungan yang positif.

Tidak signifikannya perbedaan risiko antara saham berbasis syariah dan non syariah mungkin didasari proses seleksi berdasarkan kriteria khusus terhadap saham-saham yang berkategori syariah maupun non syariah tidak terlalu mempengaruhi kinerja kedua jenis saham. Sekali lagi yang menentukan besar kecilnya risiko saham adalah permintaan dan penawaran pasar, keputusan investor, faktor makro ekonomi dan non ekonomi, serta faktor mikro.

Berdasarkan hasil analisis perbandingan tingkat pengembalian menggunakan Uji Independent Sample T-Test didapatkan hasil bahwa saham berbasis non syariah memiliki pengembalian yang lebih tinggi dibandingkan saham berbasis syariah. Perbedaan antara pengembalian saham berbasis syariah dan non syariah sebesar 0,002740 . Berdasarkan hasil uji perbandingan menunjukkan bahwa tidak ada perbedaan yang signifikan atas 
pengembalian antara sahama-saham berbasis syariah dan non syariah.

Hasil ini sesuai dengan teori yang dikemukakan oleh Jogiyanto (2013), yang menyatakan bahwa semakin tinggi risiko suatu sekuritas maka semakin besar pengembalian yang akan didapatkan. Pada hasil uji perbandingan risiko didapatkan hasil bahwa tingkat risiko saham berbasis syariah lebih kecil dari risiko saham berbasis non syariah. Sejalan dengan hasil uji perbandingan pengembalian kedua jenis saham yang menyatakan bahwa pengembalian saham berbasis syariah lebih kecil dibandingakan dengan risiko saham berbasis non syariah. Dapat disimpulkan bahwa pengembalian dan risiko saham memang memiliki hubungan yang positif.

Hasil penelitian ini sejalan dengan penelitian Wijiyantoro (2014) yang dalam penelitiannya menggunakan sampel saham murni syariah dari Jakarta Islamic Index (JII) dan murni non syariah dari Indeks LQ45, tetapi menggunakan alat uji yang berbeda. Hasil penelitian Wijiyantoro (2014) juga menunjukkan tidak adanya perbedaan yang signifikan atas pengembalian dan risiko antara saham syariah dan non syariah. Penelitian Wijyantoro juga menunjukkan hasil bahwa saham syariah memiliki pengembalian yang lebih tinggi dibandingkan dengan saham non syariah, sedangkan pada penelitian ini adalah sebaliknya.

Tidak signifikannya perbedaan pengembalian antara saham berbasis syariah dan non syariah didasari oleh sistem perdagangan yang masih sama di antara keduanya. Kriteria-kriteria khusus yang ditetapkan untuk saham berbasis syariah pun nyatanya tidak terlalu berpengaruh signifikan terhadap tingkat pengembalian mengingat perbedaan antara kedua jenis saham hanya terletak pada jenis produk yang ditawarkan dan proporsi modal serta laba.

\section{SIMPULAN}

Berdasarkan hasil analisis data dan pembahasan terhadap perbandingan risiko dan pengembalian antara sahamsaham yang berbasis syariah dan non syariah di Bursa Efek Indonesia dapat diambil kesimpulan bahwa tidak ada perbedaan yang signifikan atas risiko (risk) dan pengembalian (return) saham-saham berbasis syariah dan non syariah selama periode pengamatan tahun 20102014. Hal ini dibuktikan dengan hasil uji perbandingan menggunakan Uji Independent Sample T-Tests terhadap risiko dan pengembalian antara saham-saham berbasis syariah dan non syariah yang tidak signifikan.

Saran bagi Investor Saham Berbasis Syariah dan Non Syariah agar saham berbasis syariah untuk menjadi instrumen investasi karena selain sesuai dengan hukum syariah, saham berbasis syariah juga memiliki pengembalian yang cukup baik dengan tingkat risiko yang cukup sebanding dan tidak terlalu tinggi jika dibandingkan dengan saham berbasis non syariah.

Bagi emiten saham berbasis syariah dan non syariah sebaiknya melakukan analisis dini terhadap risiko-risiko makro maupun mikro yang dapat mengancam harga sahamnya. Melihat beberapa periode masih ditemui beberapa return yang nilainya negatif sehingga dapat 
mengurangi minat para investor untuk membeli saham yang diterbitkannya. Selain analis dini terhadap risiko-risiko yang akan timbul, perbaikan kinerja saat ini juga diperlukan untuk sesegera mungkin meningkatkan keuntungan sehingga harga saham juga meningkat.

\section{DAFTAR PUSTAKA}

Aini, Nur. 2015. Pasar Modal Syariah Belum Populer. [Online].

http://www.republika.co.id/beri ta/ekonomi/syariahekonomi/15/10/20/nwhyyq382pasar-modal-syariah-belumpopuler. Diakses 23 Oktober 2015.

Badan Pusata Statistik. 2010. Penduduk Menurut Wilayah dan Agama yang Dianut. [Online].

http://sp2010.bps.go.id/index.p $\mathrm{hp} /$ site/tabel?tid=321. Diakses pada 20 Oktober 2015.

Bursa Efek Indonesia. 2010-2014. IDX Yearly Statistics. [Online]. http://www.idx.co.id/id-

id/beranda/publikasi/statistik.as px. Diakses pada 05 Januari 2016.

Bursa Efek Indonesia. 2010-2014. Indeks Konstituen. [Online]. http://www.idx.co.id/id$\mathrm{id} /$ beranda/informasipasar/daft arefek/indekskonstituen.aspx.

Diakses pada 11 Desember 2015.

Jogiyanto. 2007. Metode Penelitian Bisnis: Salah Kaprah dan Pengalaman-pengalaman (Edisi 2007). Yogyakarta: BPFE.
Jogiyanto. 2013. Teori Portofolio dan Analisis Investasi (Edisi 7). Yogyakarta: BPFE.

Mamduh dan Syafiq. 2012. Perbandingan Kinerja Investasi Syariah Dan Konvensional: $\quad$ Studi Pada Jakarta Islamic Index (JII) Dan Index LQ45. Jurnal Ekonomi dan Bisnis Islam. Vol. VII. No. 1. [Online]. http://journal.uinsuka.ac.id/media/artikel/EBS12 VII01-

Ekbisi\%20Des\%2020122\%20(16-27).pdf. Diakses pada 17 November 2015.

Otoritas Jasa Keuangan. Keputusan Ketua Badan Pengawas Pasar Modal dan Lembaga Keuangan Nomor KEP-208/BL/2012 tentang Kriteria dan Penerbitan Daftar Efek Syariah. [Online]. www.ojk.go.id/id/kanal/pasarmodal/regulasi/regulasi-pasarmodalsyariah/Documents/IIK1_1389 002343.pdf. Diakses pada 20 Oktober 2015.

Priyatno, Dwi. 2011. Belajar Cepat Olah Data Statistik dengan SPSS. Yogyakarta: Andi.

Samsul, Muhammad. 2006. Pasar Modal dan Manajemen Portofolio. Surabaya: Erlangga.

Sugianto, Danang. 2015. BEI Sebut Investor Di Saham Syariah Tidak Sampai 1\%. [Online]. http://economy.okezone.com/re ad/2015/10/05/278/1226365/be i-sebut-investor-di-saham- 
syariah-tak-sampai-1. Diakses 23 Oktober 2015.

Sugiyono. 2013. Statistika untuk Penelitian. Bandung: Alfabeta.

Sutedi, Adrian. 2011. Pasar Modal Syariah. Jakarta: Sinar Grafika

Wijiyantoro, Rezki Deny. 2013. Analisis Perbandingan Risiko dan Return Saham Jakarta Islamic Index dan $L Q \quad 45$ Periode Januari 2012 Februari 2013. Skripsi pada
IAIN Walisongo Semarang. [Online].

http://eprints.walisongo.ac.id/1 170/. Diakses pada 01 Desember 2015.

Zumir, Zalbi. 2011. Manajemen Portofolio Penerapannya Dalam Investasi Saham. Jakarta: Salemba Empat.

Yahoo Finance. 2010-2014. Jakarta Composite Index Historical Price. [Online].

http://finance.yahoo.com/q/hp?s=\%5 EJKSE+Historical+Prices. Diakses pada 26 Februari 201 